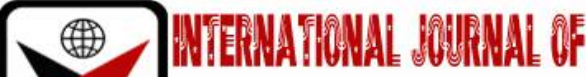

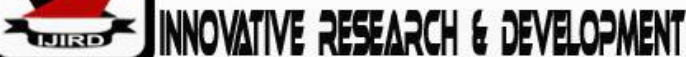

ISSN 2278 - 0211 (Online)

\section{Organizationall Integrity and Performance of Fast Food Companies in Port Harcourt, Nigeria}

Aeba, Barine
PG. Student, Department of Management, Faculty of Management Sciences,
Rivers State University, Port Harcourt, Nigeria
Dr. Justin M. O. Gabriel
Senior Lecturer, Department of Management, Faculty of Management Sciences,
Rivers State University, Port Harcourt, Nigeria
Dr. S. Lebura
Lecturer, Department of Management, Faculty of Management Sciences,
Rivers State University, Port Harcourt, Nigeria

\section{Abstract:}

This study was undertaken to determine the association of organizational integrity with performance of fast food companies in Port Harcourt, Nigeria. The Explanatory Cross Sectional Research Design was employed, using a structured questionnaire on a five point Likert scale of Very Great Extent (VGE), Great Extent (GE), Not Applicable (NA), Low Extent (LE) and Very Low Extent (VLE) to elicit responses from 248 subjects randomly selected from the population of about 650 employees using the Taro Yemen formula. With the aid of Statistical Package for Social Science (SPSS), the Spearman rank order correlation coefficient was used to analyze data. The Results revealed a high degree of correlation between the dimension of the Criterion variable (integrity) and the Predictor variable measured in terms of productivity and increase in Market share. This implies a significant relationship between Integrity and organizational performance with coefficient of determination value $R 2=.927$ representing $92.7 \%$ concordance between the predictor and criterion variables. The study concluded that virtuousness is positively related to organizational performance and serves both amplifying and buffering functions. It is therefore recommended among others that Fast food companies should ensure that a high level of integrity is maintained in order to build trust and confidence amongst staff members and other stakeholders.

Keywords: Organizational integrity, performance, fast food, productivity, market share

\section{Introduction}

Several studies have previously been conducted to determine the association of organizational integrity and performance. Among several others, Sutcliffe \& Vogus, (2003); Fredrickson, (2003); Dienstbier \& Zillig, (2002); Masten \& Reed, (2002); Hatch, (1999); Seligman, Schulman, DeRubeis, \& Hollon, (1999) demonstrated that when virtuousness is expressed in organizations (as when leaders or exemplars manifest courageous or compassionate behaviours), or when organizations recognize and legitimize virtuous behaviours (as when courageous or compassionate acts are recognized and applauded), virtuousness becomes self-reinforcing, and it fosters resilience against negative and challenging obstacles.

Grünberg (2004) observes that for decades, the term 'organizational performance' has been defined from a wide range of perspectives. Some scholars distinguish it as multi-dimensional, proposing that each organization has particular criteria for organizational performance, and the criteria applicable in one organization may not be appropriate in others. Beyond these definitions, empirical study of organizational virtuousness is at most scanty. There are however evidences of studies in a hospital in Malasia on self-control, morality and love. The result showed high degree of correlation between exhibition of love and employee productivity. It is interesting to note that from existing studies so far examined, the Unit of analysis comprises public establishments while the Geographical Unit of analysis are England and Malasia.

Therefore, this is a pioneering effort at studying the association of Organizational integrity and performance of fast food companies, a major industry in the Nigerian's agro-based economy and aims at supplying fresh empirical data and update on existing literature.

\section{Literature Review}

\subsection{Theoretical Foundation}

Under the Strategic Management School of Thought, organizational virtue is closely related to Stakeholder Theory as both deal with perceptions and feelings about the organization held by stakeholders. The link does not exist from the 
perspectives of the Aristotelian school whose focus is individual virtues. Followers of MacIntyre generally do not seem to view strategic results regarding external goods as being part of virtue, per se.

A virtue is a special character trait that is pleasing both to other people and to us, according to a famous political philosopher David Hume. At the level of organization, virtue is a character trait of an organization which satisfies both employees (internal stakeholders) and customers (external stakeholders). The assumption of internal (the self) and external stakeholders' (others) satisfaction is important. This attribute of organizational virtue distinguishes itself from other duty-based ethics based on self-sacrifice or selflessness. Hartman (1998) refers to people working under an organizational culture driven by the rationalist business ethics as 'happy robots' whose satisfaction is sacrificed, which is not virtuous.

This corresponds to the core theme of Stakeholder Theory; that is, a corporation's survival and continuing success depends on the firm's ability to satisfy its primary stakeholder groups: customers, employees, suppliers, shareholders, and public stakeholders (Clarkson 1995). Stakeholder theory suggests that a favourable reputation and the perception which each company has established with its various stakeholders as to its virtuous character (such as competence, honesty, loyalty, and hard work) contribute to the firm's successful performance (Cornell and Shapiro 1987).

\subsection{The Concept of Organizational Integrity}

Organizational Integrity is one of the dimensions of Organizational Virtuousness. Thornton (2013) observes that the word integrity evolved from the Latin adjective integer, meaning whole or complete. She therefore defines Integrity as the full alignment in what the organization thinks, says and does. It is the ethical integrity of the individual actors, the ethical quality of their interaction as well as that of the dominating norms, activities, decision making procedures and results within a given organization (Palazzo, 2007). Available literature provides some conceptualizations of integrity systems (Pope, 1996; Head et al., 2008; Huberts et al., 2008a). This work demonstrates that these are either descriptive or prescriptive; none is explanatory nor has any been tested empirically for their effectiveness. Descriptive empirical research to date suggests that there may be different configurations of policies, institutions and practices that may lead to the same results, be it high or low integrity performance (Doig and McIvor, 2003, 2008; Head et al., 2008; Huberts et al, 2008a; Quah, 2010; Transparency International country reports). This suggests that variable-oriented conceptual models that can be tested with statistical regression analyses or structural equation models are inappropriate (Byrne and Ragin, 2010).

Virtuousness in organizations, in other words, is unlikely to capture attention without pragmatic outcomes. Fortunately, there is reason to believe that virtuousness and performance in organizations are positively related and mutually reinforcing. This association is explained by two key attributes of virtuousness:

- Amplifying qualities - that which can foster escalating positive consequences, and

- Buffering qualities — that which can protect against negative encroachments.

\subsection{The Concept of Organizational Performance}

Recently, researchers have emphasised that understanding organizational performance can help to distinguish techniques for improvement (Halachmi 2005; Dess and Robinson 1984). Academic researchers have described organizational performance as an umbrella term for all concepts that consider the success of a company and its activities. Different organizations have different purposes in running their business. Therefore, the determined goals of each organization may be different and the levels of organizational performance may be varied (Fan et al. 2014). Organizational performance could be defined as the ability to reach a desired objective or the degree to which anticipated results are achieved (Stefan 2005). It could also be well-defined multi-dimensionally by looking at four different categories:

- Achieving organizational goals,

- Increasing resourcefulness,

- $\quad$ Satisfying customers, and

- Improving internal processes (Cameron 1986; Redshaw 2001).

\subsubsection{Market Share}

Market share refers to the percentage of sales a company has in a specific market within a specific time period. Higher market share translates into higher profits. Gaining or building market share is an offensive or attack strategy to improve the company's standing in the market (Sarkissian \& Schill, 2010 cited in Okparanta and Oparanma, 2018). It is the measure of customers' preference for one product over another. It implies greater sales, less product selling price and higher entry barriers to new entrants. Market share is said to be a key indicator of market competitiveness. Davies (2000) cited in Paul-Igbara \& Konya (2018) opines that changes in market share represent improvement or declining performance relative to competitors. It inherently reflects the attainment or loss of competitive advantage. A higher market share also means that if the market expands, the leader gains more than the rest, implying also that the market leader has to make deliberate efforts to expand the market for its own growth (Okparata, op cit).

\subsubsection{Productivity}

Productivity is a scientific concept, and hence can be logically defined and empirically observed. It can also be measured in quantitative terms, which qualifies it as a variable. Therefore, it can be defined and measured in absolute or relative terms. However, an absolute definition of productivity is not very useful; it is much more useful as a concept dealing with relative productivity or as a productivity factor, Vora, (2002). Productivity is useful as a relative measure of actual output of production compared to the actual input of resources, measured across time or against common entities. 
As output increases for a level of input, or as the amount of input decreases for a constant level of output, an increase in productivity occurs. Therefore, a "productivity measure" describes how well the resources of an organization are being used to produce output, Tangen, (2002).

Productivity is often confused with efficiency. Efficiency is generally seen as the ratio of the time needed to perform a task to some predetermined standard time. However, doing unnecessary work efficiently is not exactly being productive. It would be more correct to interpret productivity as a measure of effectiveness (doing the right thing efficiently), which is outcome-oriented rather than output-oriented, Parham and Zheng, (2006). Productivity is usually expressed in one of three forms: partial factor productivity, multifactor productivity, and total productivity. Productivity is an overall measure of the ability to produce a good or service.

\section{Research Methodology}

\subsection{Research Design}

This is the plan and structure of investigation that would be used to obtain answers to research questions (Ogula, 1995). In this study, Explanatory cross-sectional design was preferred because it shows the characteristics of the population, current practices, conditions or needs and provides information for generating research questions. As per Mugenda and Mugenda (2013), Explanatory research design helps researchers to explore existing status of two or more variables. A large percentage of Social Science Research make use of Explanatory Research design as it enables the researcher understand the details of a particular situation, study cause and effect, and relationship between two variables, Asawo, (2018). Breakdown of target population of the study is as shown the table below:

\begin{tabular}{|c|c|c|}
\hline S/N & Names of Fast food Companies & No. of employees \\
\hline 1 & Tantalizers & 35 \\
\hline 2. & Spar & 38 \\
\hline 3. & Chicken Republic & 45 \\
\hline 4. & Durables & 30 \\
\hline 5. & Skippers & 48 \\
\hline 6. & Pepperoni & 112 \\
\hline 7. & Genesis & 81 \\
\hline 8. & Mr. Bigg's & 61 \\
\hline 9. & The Promise & 77 \\
\hline 10. & Kilimanjaro & 53 \\
\hline 11. & Happy Bite & 650 \\
\hline Total & & \\
\hline
\end{tabular}

Table 1: Fast Food Companies in Port Harcourt and Number of Employees Source: Rivers State Yellow Pages Directory (2013-2014)

The researcher used the stratified random sampling technique. The technique is preferred because it helps the researcher divide the sample into appropriate strata that are mutually exclusive. According to Coopers and Schindler (2000), stratified sampling technique increases statistical efficiency of a sample and provides adequate data for analyzing the various sub-populations and enables different research methods and procedures to be used in different strata. formula is;

In determining the sample size, the Taro Yemen formula was used to compute the sample size of study. The

$$
\mathrm{n}=\frac{\mathrm{N}}{1+N(\mathrm{e})^{2}}
$$

Where: $\mathbf{n}=$ sample size; $\mathbf{N}=$ population size; $\mathbf{e}=$ degree of confidence error term $5 \%$;

And Population $(\mathrm{N}=650)$

$$
650
$$

$\mathrm{n}=\underline{1+650(.05)^{2}}$

$$
\begin{array}{ll}
= & 247.61 \\
= & 248
\end{array}
$$

\subsection{Data Collection}

Structured questionnaire was used to collect data. Structured or close-ended questionnaire are those that have definite, concrete and predetermined questions and are accompanied by a list of possible alternatives from which respondents select the answers that best describe the situation. Structured questionnaire was used in the study because they reduce the amount of thinking that a respondent needs to undertake to complete the task which leads to higher response and more accurate data as well as considering the kind of work done by the respondents (Hulin, 1969). 


\subsection{Validity of Instruments}

The accuracy of data collected largely depended on the data collection instruments in terms of validity. Validity as noted by Robinson (2002) is the degree to which results obtained from the analysis of the data actually represents the phenomenon under study. Validity was ascertained by having all the objective questions included in the questionnaire.

\subsection{Reliability of Instruments}

According to Borg and Gall (1986), reliability is the level of internal consistency or stability of the measuring device overtime. In order to test reliability of the instruments, internal consistency was applied using Cronbach's alpha which was popularized by Cronbach (1954). The value ranges between 0-1 with reliability increasing with increase in value. Coefficient of values 0.7 and above will be considered as ideal (Mugenda, 2008). Therefore, the Reliability Analysis of this study is shown in Table 3 below. In the Table, the variables represent the measures of the Dependent and Independent variables.

\begin{tabular}{|c|c|c|}
\hline Variables & Items & Alpha Value \\
\hline Integrity & 4 & 0.768 \\
\hline Increase in Market share & 4 & 0.868 \\
Productivity & 4 & 0.832 \\
\hline Total & 12 & 2.468 \\
\hline
\end{tabular}

Table 3: Reliability Analysis

Source: Research Data, 2018

\section{Data Analysis}

The study was conducted to examine the effect of organizational virtuousness on performance of fast food companies in Port Harcourt. A total of two hundred and forty-eight (248) copies of questionnaire were distributed, out of which, one hundred and seventy-two (172) representing $69.35 \%$ of total questionnaire were fully completed and returned while seventy-six (76) or $30.65 \%$ copies were not returned.

The statistical tools used here comprise of both, descriptive and inferential statistical techniques. This is necessitated by the fact that the analysis is divided into several stages. The entire work is aimed at first assessing the significance of the manifestations of the variables within the context of the organizations examined using descriptive measures such as the mean and standard deviation, then thereafter the use of inferential statistical tools such as the Spearman rank order correlation in the assessment of significant level of correlations, and the coefficient of determination in the assessment of the extent of correlation between the two variables (organizational virtuousness and performance of fast food companies).

- $\mathrm{H}_{01}$ : There is no significant relationship between integrity and increase in market share of fast food companies in Port-Harcourt

\begin{tabular}{|c|c|c|c|c|c|}
\hline & & Integrity & Productivity & Alternatives & $\begin{array}{c}\text { Increase in } \\
\text { market share }\end{array}$ \\
\hline \multirow{4}{*}{ Integrity } & Correlation & 1 & $.840^{*}$ & $.896^{*}$ & $.756^{*}$ \\
\cline { 2 - 6 } & Sig. (2-tailed) & & .000 & .000 & .000 \\
\cline { 2 - 6 } & $\mathrm{N}$ & 172 & 172 & 172 & 172 \\
\hline Productivity & Correlation & $.640^{*}$ & $.927^{*}$ & $.901^{*}$ & 1 \\
\cline { 2 - 6 } & Sig. (2-tailed) & .000 & .000 & .000 & .000 \\
\cline { 2 - 6 } & $\mathrm{N}$ & 172 & 172 & & $.901^{*}$ \\
\hline Alternative & Correlation & $.896^{*}$ & $.901^{*}$ & 1 & .000 \\
\cline { 2 - 6 } & Sig. (2-tailed) & .000 & .000 & & 172 \\
\cline { 2 - 6 } & $\mathrm{N}$ & 172 & 172 & 172 & .000 \\
\hline Market share & Correlation & $.756^{*}$ & 1 & $.001^{*}$ & 172 \\
\cline { 2 - 6 } & Sig. (2-tailed) & .000 & .000 & .000 & .000 \\
\cline { 2 - 6 } & $\mathrm{N}$ & 172 & 172 & 172 & 172 \\
\hline
\end{tabular}

Table 4: Organizational Integrity and the Measures of Performance

Source: Field Survey $2018 R^{2}=0.560$

* Correlation Is Significant at the 0.05 Level (2-Tailed)

The relationship between organizational integrity and increase in market share is revealed to be significant given the observed correlation: . $756, \mathrm{R}^{2}=0.572$ and a p-value of .000 which is less than 0.05 (table 4.7). The correlation value shows a moderate and significant relationship between both variables at a 95\% confidence interval also implying a 0.05 level of significance. The positive sign value of .756 reveals a direct relationship between integrity and increase in market share, which indicates that the more fast food company exhibit or increases integrity, the share of market size of the fast food companies will increase. Therefore, the hypothesis of no significant relationship between integrity and increase in market share of fast food companies in Port-Harcourt, Null hypothesis is rejected based on the decision rule of $\mathrm{P}<0.05$. 
We therefore accept the alternative hypothesis and restate the null that integrity is significantly associated with increase in market share.

\subsection{Discussion of Findings}

The hypotheses tested revealed strong significant relationship between the Integrity and measures of organizational performance. The result of the test of the relationship between integrity and increase in market share of fast food companies in Port Harcourt shows that a company that maintains good integrity will of course have an increase in its market share. This agrees with the early work done by Choa (1993). He concluded that an organization that maintains good and upright integrity will encourage employees to increase their productivity which will lead to enhanced performance. This revealed a positive relationship between the two variables. Consequently, good integrity will increase the market share. That is, companies with good record of trust and integrity will attract more customers. Putnam (2000) asserts that, integrity attracts effectiveness and activeness of an individual. Therefore, if an organization is able to show love to an employee, the employee reciprocates through enhanced performances. This finding further supports the earlier study of Freeman \& Misha (1993) to the effect that employees' display of integrity directly translates to enhanced contribution towards achieving increase in its market share.

\section{Conclusion}

The primary objective of this study was to analyze the concept of organizational Integrity in relation to performance. Thus far, particularly in fast food companies, empirical researchers have seldom examined the idea of virtuousness, although it is now beginning to merit some consideration. The findings of this study suggest that, even in organizations expected to suffer from the deleterious effects of downsizing, positive relationship exists between virtuousness and organizational performance. When virtuous behaviour is displayed by organization members and enabled by organizational systems and processes, the organization achieves higher levels of desired outcomes. Explanations for why these relationships exist have been offered, bordering on the amplifying and buffering functions of organizational virtuousness.

\subsection{Contribution to Knowledge}

The major emphasis of the study was on organizational virtuousness and performance. The present study supports existing literature that virtuousness is positively related to performance. The major contribution of this study is that the study was related to fast food companies in Port Harcourt, thus providing empirical data and analyses that have provided substantial materials to fill up existing gaps in the scope of the study. This covers the geographical, extent and unit scope. The present study further proves that the maintenance of organizational virtuousness is crucial to the overall performance (productivity and increase in market share) of fast food companies in Port Harcourt.

\subsection{Recommendations}

- $\quad$ Fast food companies should ensure that a high level of integrity is maintained at all times and across all levels of management in order to build trust and confidence amongst members of staff.

- Organizations should also ensure that issues that bother on their integrity are promptly detected and addressed.

- Organizations should ensure that workers and their supervisors gain optimum satisfaction in the services they render daily to the organization. This can be achieved by instituting a clear line of communication to ensure free flow of vital information.

\section{References}

i. $\quad$ Ariyor, 0. (2005). Junk food in Lagos. Journal of healthy living XL 45(13). 254-288.

ii. Asawo, S. P. (2018). Lecture notes on Research Methodology, Department of Management, Rivers State University, Port Harcourt

iii. Baumeister, R.F. \& Exline, J. J. (1999). Virtue, personality, and social relations: Self-control as the moral muscle. Journal of Personality, 67: 1165-1194.

iv. Brown, H., \& Dacin, B., (1997). The Role of Virtuousness in Transaction, An empirical investigation of exhibitors and visitors with selling motives. International Marketing Review, 2, 39-53. http://dx.doi.org/10.2307/125212.

v. Byrne, C.D., \& Ragin K., (2010). Why act for the public good? Four answers. Personality and Social Psychology Bulletin. 20:603-610.

vi. Cameron, Kim S. (1986). A study of organizational effectiveness and its predictors.” Management Science, 32: 87112.

vii. Cameron, K.S. \& Caza, A. (2003). Organizational \& leadership virtues and the role of forgiveness." Journal of Leadership and Organizational Studies, 9:33-48.

viii. Chapman, J.W., \& Galston, W.A. (1992). Virtue. New York: New York University Press.

ix. Chun, T., (2016). An Exploratory Investigation into Current Practice and the Role of Firm Orientation. Working Paper, Marketing Science Institute, No.99-114.

x. $\quad$ Comte-Sponville, L., (2001). Virtuous Behaviour in Work Place. Industrial Harmony Trust, 56: 245-435

xi. Cooper, D. Schindler, V., (2000). Working with sample in Research. Journal of Social Sciences, 45-49.

xii. Cornell, H. \& Shapiro, W., (1987). Measuring the Effect of Virtuousness on Performance. Journal of management, 25: 812-846. 
xiii. Daily, M., \& Kirk, L., (1992). Positive psychology, positive prevention, and positive therapy.” In Snyder, C.R. and Lopez, Shane J. (Eds.) Handbook of Positive Psychology, (pp. 3-9), New York: Oxford University Press.

xiv. Dent, T. (1984). The Moral Aspect of Virtuousness. Hand book of positive psychology, (pp456-465) New York University Press.

xv. Dess, B., \& Robinson, H., (1984). When Sales People Fail, Assessing Blame. Industrial Marketing Management Journal, 1, 19-26.

xvi. Diestbier, C., \& Zillig, (2002). Integrating the principle Of Uprightness in Work place. The Organization Journal of Occupation Psychology. 63, 1-18.

xvii. Doherty, R., (1995). The Harmony of the Soul: Mental Health and Moral Virtue Reconsidered. Albany, NY: State University of New York Press.

xviii. Doig, A., \& McIvor, N., (2003). Retrospective Reports of strategic-Level Managers; Guidelines for Increasing Their Accuracy. Strategic Management Journal, 2, 171-180.

xix. Emmons, Z., (1999). The Measures and Antecedents of Affective, and warm to the organization. Journal of Occupation Psychology. 63, 1-18.

xx. Fan, T., Schlacter, J. L., \& Wolfe, W. G. (2014). Organizational Performance in Retrospect, Journal Academics in Australia. 8(86-95).

xxi. Fredrickson, J., (2003). Getting Right Through Moral Change, Organizational Perspective. Journal of Occupation Psychology. 63, 1-18.

xxii. Gauzente, L., \& Ranchhod, F., (2001). The Driving Force of Organization in Malaysia, International Journal of Economic Development Research and Investment, 12(4).

xxiii. Gilliland, A. (1993). Factors of Organizational Performance. Journal of management science, 5(6):122-132.

xxiv. Grunberg, H., (2004). Advancing management theory, Reports of strategic-Level Managers; Guidelines for Increasing Their Accuracy. Strategic Management Journal, 2, 171-180.

xxv. Halachmi, R., (2005). Manufacturer Instinct in work place and Industrial Harmony promotions. Journal of Marketing, 27, 428-444.

xxvi. Hartman, K. (1998). The dual motives of participants at international trade shows; An empirical investigation of exhibitors and visitors with selling motives. International Marketing Review, 2, 39-53. http://dx.doi.org/10.2307/125212.

xxvii. Hatch, O., (1999). Institutional Standard and Effect and management development, Journal of academic development, 34(9), 567-597.

xxviii. Head, R.T., Huberts, N., Lock, M \& Mclvor, N., (2008). Retrospective Reports of strategic-Level Managers; Guidelines for Increasing Their Accuracy. Strategic Management Journal, 2, 171-180.

xxix. Huberts, G. P., \& Power, D. J. (2008a). Retrospective Reports of strategic-Level Managers; Guidelines for Increasing Their Accuracy. Strategic Management Journal, 2, 171-180.

xxx. Koh, K., \& Boo, H., (2001). The virtues of positive psychology: The rapprochement and challenges of the affirmative postmodern perspective." Journal for the Theory of Social Behaviour ${ }_{2}$ 31: 241-260.

xxxi. MacIntyre, L. (1984). Defining virtuous Attitude. Strategic Management Journal, 2, 171-180.

xxxii. Masten, D., Reed, Z., (2002). Handbook of Positive Psychology, (pp. 257-276) New York: Oxford University Press.

xxxiii. McGuire, K., Ryff, G., \& Frey, K., (1988). Understanding League Drive in Management, Journal of management innovation. 9, 764-769.

xxxiv. $\quad$ Mugenda, M., (2013). Empirical Approach in Management Research, Prentice Hall Publication. 56-76.

xxxv. Ogunlade, M. (2008). Challenges of Fast Food in Nigeria. Guardian newspaper, 6(24).

xxxvi. Ogula, K., (1995). When compassion and justice conflict. Journal of Personality and Social Psychology, 68: 10421054.

xxxvii. Okparanta, C. N. \& Oparanma, A. O. (2018). Employee Trust and Performance of Multinational Oil Companies in Port Harcourt, Nigeria. West African Journal of Business, 12(3),144-160.

xxxviii. Palazzo G. (2007). Organizational Integrity - Understanding the Dimensions of Ethical and Unethical Behaviour in Corporations. In: Zimmerli W.C., Holzinger M., Richard K. (eds) Corporate Ethics and Corporate Governance. Springer, Berlin, Heidelberg

xxxix. Paul-Igbara, J. B. \& Konya, K. (2018). The Impact of Training on Organizational Performance Deposit Money Banks in Port Harcourt. West African Journal of Business, 12(3),63-75.

xl. Pope, S., (1996). Analyses of Effect of Virtuousness in Employee productivity, Ph. D Dissertation, University of South Carolina. Marketing science journal, 10, 1-3.

xli. Quah, S., (2010). Quality management and organizational virtuousness In Workplace. Journal of Industrial Relation; African perspective 3(45) 23-34.

xlii. $\quad$ Raimi, K., \& Towobola, R., (2011). Eating Healthy food outside Home. Journal of health watch in Nigeria 8, 667687.

xliii. Redshaw, N., (2001). When compassion and justice conflict. Journal of Personality and Social Psychology, 68: 1042-1054.

xliv. $\quad$ Ryff, G., \& Singer, L., (1998). The Harmony of the Soul: Mental Health and Moral Virtue Reconsidered. Albany, NY: State University of New York Press.

xlv. Seligman, M. E.P., Schulman, P., DeRubeis, R.J., and Hollon, S.D. (1999). The prevention of depression and anxiety. Prevention and Treatment. http://journals.apa.org/prevention/ 
xlvi. Spicer, D., (1978). International Journal of Productivity and Performanceumar Management, 1\&2, 137-145. http://dx.doi.org/10.1108/17410400510576621

xlvii. Stefan, F., (2005). Applied Industrial Relation in Manufacturing Companies in Jakaranta. Management Journal. $4(6)$.

xlviii. Sutcliff, R. \& Vogus, C.Y. (2003). Structural and contextual correlates of charged Behavior in product development teams. Journal of Product Innovation Management. 18:154-168.

xlix. Thornton, L.F. (2013). 7 Lenses: Learning the Principles and Practices of Ethical Leadership, VA: Leading in Context

l. Weiner, N.O. (1993). The Harmony of the Soul: Mental Health and Moral Virtue Reconsidered. Albany, NY: State University of New York Press. 